\title{
KNOCK! KNOCK! WHO'S THERE? AN ETHNOARCHAEOLOGICAL APPROACH IN FRENCH GUIANA
}

\author{
Stéphen Rostain
}

\begin{abstract}
Amazonia and the Guianas possess exceptional potential for ethnoarchaeological studies because of the precolumbian heritage of modern-day Amerindian people. Surprisingly, minimal scholarship of this nature has been conducted in the South American lowlands. On the French Guiana coast, Maillard, a small Palikur village, was abruptly abandoned in 1990. I initiated an ethnoarchaeological study to pinpoint important differences between the interpretation of archaeological and ethnographic data. I recorded the topography of features and remains, compiled an inventory of artifacts and the contents of discard areas, inventoried the cultivated trees present, and described the characteristics of the surroundings. After analyzing the data using classical methods of archaeological inference to obtain a complete reconstruction of the village and the customs of its inhabitants, I invited the chief into his now-abandoned village to describe the settlement as it was while inhabited. In the twenty years since, I have made several visits to track the natural degradation of the site. This ethnoarchaeological approach shows that archaeologists dealing with field data can make many mistakes. Conversely, ethnographic accounts are distorted by the cultural rules and interdictions of interviewees. This experiment suggests the need for prudence in our interpretations and hypotheses, especially in the tropical lowlands, where archaeological preservation is particularly poor.
\end{abstract}

La Amazonía y las Guayanas ofrecen un potencial excepcional para los estudios etnoarqueológicos, dado que su actual población indígena es heredera de los grupos precolombinos que habitaron las mismas regiones. Sorprendentemente, se han realizado escasas investigaciones de esta disciplina en las tierras bajas de América del Sur. En 1990, en la costa de la Guayana Francesa, la pequeña aldea de Palikur fue abandonada de manera repentina. Esto brindó la oportunidad de iniciar de inmediato un estudio etnoarqueológico original. De esta manera, se organizó un trabajo arqueológico de campo en el asentamiento, a partir del cual se registró la topografía de rasgos y restos, se realizó un inventario de artefactos y contenidos de las áreas de desecho y se describieron los árboles cultivados y los terrenos cercanos, entre otras tareas. Los datos obtenidos fueron estudiados para evaluar las interpretaciones que se podrían hacer siguiendo procedimientos clásicos, con el fin de obtener una reconstrucción completa del pueblo y las costumbres de sus habitantes. Una vez concluido el estudio arqueológico, se invitó al jefe del pueblo abandonado para que explicara cómo era el asentamiento anteriormente. Luego, durante veinte años, se efectuaron varias visitas para seguir los procesos naturales de deterioro del sitio y la desaparición de los rasgos antrópicos. El estudio desembocó en la constatación de las grandes diferencias existentes entre la interpretación de los datos arqueológicos y los etnográficos. Este tipo de metodología etnoarqueológica mostró que los arqueólogos que dependen exclusivamente de datos de campo pueden cometer varios errores. Por el contrario, la entrevista etnográfica no permite distorsiones, puesto que está profundamente influenciada por las reglas y prohibiciones culturales. Este experimento incita a una mayor prudencia en nuestras interpretaciones e hipótesis, en especial en las tierras bajas tropicales, cuyo contexto arqueológico es bastante pobre.

"I have no house only a shadow."

(Malcolm Lowry, Under the Volcano, 1947)

$\mathrm{I}$ $\mathrm{n}$ the Amazonian region, it is very common for archaeologists to base their interpretations on ethnographic comparisons because of the perceived continuity of Amerindian cultures from precolumbian times. Nevertheless, this can lead to significant misunderstandings because modern Amerindian cultures of Amazonia differ in important ways from prehistoric ones. Similarly, ethnic attribution does not always correspond to differences in material culture (Duin 2014; Mans 2014). One solution to the problem of checking the validity of comparisons between contemporary and ancient native

Stéphen Rostain — CNRS (National Center for Scientific Research), UMR 8096 "Archaeology of the Americas" Maison Archéologie \& Ethnologie, 21 allée de l’Université, 92023, Nanterre Cedex, France (stephen.rostain@cnrs.fr)

Latin American Antiquity 28(1), 2017, pp. 6-27

Copyright ( 2017 by the Society for American Archaeology

doi:10.1017/laq.2016.5 
cultures could be the ethnoarchaeological method. Ethnoarchaeology can be defined as the use of ethnography to answer archaeological questions (see Supplemental Information 1). Ethnoarchaeology can also refer to using archaeological approaches in an ethnographic context. My ethnoarchaeological experiment was conducted in a modern Amerindian village using archaeological methodology to evaluate the validity of inferential reasoning used by archaeologists to explain their data.

Amazonia offers exceptional potential for ethnoarchaeological studies because the Amerindian people residing in this region are the successors of precolumbian societies. Nevertheless, few researchers have conducted such investigations in Amazonia up to now. Annette Laming-Emperaire and colleagues (1978) conducted an ethnoarchaeological investigation in a Xetá settlement in Brazil, with a special focus on the lithic technology that was still being used. Later, students of Donald Lathrap (DeBoer and Lathrap 1979) conducted ethnoarchaeological research in various areas of the South American lowlands. In the eastern foothills of the Peruvian Andes, Peter Roe and Peter Siegel (1982; Siegel and Roe 1986) evaluated the organization of two Shipibo dwelling compounds, one from an inhabited context and the other one in a recently abandoned house, to establish correspondences between use areas and discard areas. Siegel (1990, 1991) also studied the relationship between demographic and architectural organization in a Waiwai village of Guyana. James Zeidler (1983) made a complete inventory of a modern Achuar household of Ecuador and classified the importance of each group of artifacts and each activity area.

Since these studies, little ethnoarchaeology has been conducted in Amazonia until quite recently, when researchers began to study modern villages. For instance, I used ethnoarchaeology to identify the organization of a domestic floor during a horizontal excavation of a precolumbian proto-Jivaro house in the Sangay site, Ecuador (Rostain 2006, 2011). Brenda Bowser (2004) and John Patton (Bowser and Patton 2004) analyzed the gender division of activities and spaces in Achuar and Kichwa houses of Ecuador. Gustavo Politis (2007) conducted illuminating and detailed research on the occupation, environment, settlement patterns, mobility, technology, food procurement, ideology, and many other aspects of the Colombian huntergatherer culture of the Nukak. A few other ethnoarchaeological studies have been conducted in Amazonia (see Supplemental Information 2). During the past twenty years, some doctoral dissertations have used ethnoarchaeology in the South American Eastern Lowlands (see Supplemental Information 3), but few focused on the Amerindian house.

In 1990, I conducted an ethnoarchaeological investigation in a small Amerindian village near the coastal road a few kilometers west of Cayenne in French Guiana. Before that, in 1989, I regularly worked with some men of this village during my research on precolumbian raised fields on the western coast of French Guiana (Rostain 2012). By October 1990, the village had been completely abandoned. I located the former occupants, who had migrated to a second village called Kamuyene, located $3.1 \mathrm{~km}$ to the west. I saw the opportunity to conduct an original investigation in the deserted settlement. This setting forms the basis for the ethnoarchaeological experiment in archaeological methodology featured in this paper.

First, I conducted archaeological fieldwork at the site, including mapping and excavations. Then, I interpreted this data without employing the past inhabitants of the village as a source. Although it is impossible to avoid unconscious influences, I attempted to be unbiased by basing interpretations only on features and artifacts. Obviously, a culture cannot be defined only on the basis of material remains although these can contain clues that define the inhabitant identity. This work was conducted with the intention to determine the characteristics of the material culture and the settlement characteristics of the former occupants. following the culture-historical concept as it is widely understood among archaeologists working in the South American Lowlands. In spite of centuries of colonization, hybridization, transculturation, and integration, I argue that each modern Amerindian village of the Guianas still presents ethnic specificities and particular traits that differentiate them from other 
settlements. These traits constitute a set of clues that can help identify the origin of the inhabitants. The next step in the study was to meet the former captain of the village, a title given to the most important person in an Amerindian village in French Guiana and the legal representative to French authorities. I returned to the village with the captain, who gave me his interpretation of the remains. I compared the archaeological inferences with the ethnographic evidence to reevaluate the interpretation. Since this study, I have always tried to apply the lessons learned from it to my subsequent work.

Two ethnoarchaeological studies have been conducted in the Americas that are comparable to my approach. Frederick Lange and Charles Rydberg (1972) conducted archaeological fieldwork in a recently abandoned Amerindian settlement in northern Costa Rica. They then checked their interpretations by interviewing the former inhabitants of the houses. Robson Bonnichsen (1973) carried out a similar study in a recently abandoned Amerindian house in the central Canadian Rockies known among archaeologists as Millie's camp. They used the activity area concept and checked archaeological interpretations against the accounts of the former inhabitants. My conclusions are similar to the results of these studies. During the same period (end of the 1980s), Fabienne de Pierrebourg (1999) conducted doctoral research on precolumbian and present-day Maya domestic structures in Mexico using a similar approach. More widely, several scholars have published work on formation processes of the archaeological record and on the ethnoarchaeology of abandonment processes (Cameron and Tomka 1993; Lucas 2012; Schiffer 1987).

\section{Geographic Setting}

The French Guiana coastal zone is part of the broad Quaternary sedimentary plain stretching some $1,600 \mathrm{~km}$ between the mouth of the Amazon and the Orinoco Delta. This plain is relatively narrow in French Guiana, where it is 5-40 km wide. Outcrops of the rocky shelf emerge only on the French Guiana coast in the form of small hills in Oyapock Bay, Cayenne Island, and the lower valley of the Kourou River, but the rest of the coast is low and partially flooded. The young coastal plain is differentiated from the old coastal plain. The former is a low swampy plain bordered by mangroves on the mud flats along the seashore. It is subject to tidal influences, and the seawater can flood the mangrove as far as $2 \mathrm{~km}$ into the interior. On the old coastal plain, marshes are cut by narrow and elongated sandy ridges parallel to the seashore. These are old beaches that measure some tens of meters wide and can reach more than $100 \mathrm{~km}$ long. These dry sandy ridges are preferred locations for Amerindians to build their villages.

At the beginning of the colonial period, Europeans did not favor this landscape, considering it inadequate for settlement and agriculture, with noxious air that provoked lethal fever. In contrast, precolumbian Amerindians intensively occupied this savannah environment and profoundly modified the landscape (Rostain 2008). For that reason, numerous archaeological sites have been found on these sandy formations along the Guianas coast. After their initial limited occupations on the coast, European settlers progressively advanced into the region during the seventeenth and eighteenth centuries, chasing away the Amerindian people.

The Maillard settlement was located in the traditional territory of the Kali'na, a Karib group, west of Cayenne Island. During the seventeenth century, the French Guiana coast was divided into two Amerindian territories, with Cayenne Island as a boundary. The eastern coast was the territory of the Palikur, an Aruak group, and the western coast, including Cayenne Island, was Kali'na territory. As late as the eighteenth century, many Kali'na villages were settled just west of Cayenne Island (Hurault 1989). Later, Europeans pushed Amerindians farther to the west, to the Mana River (Collomb 2015). These two groups were at war throughout the colonial period, which was characterized by temporary alliances and occasional battles. The present-day territorial situation is still the same, with the Palikur essentially located in the Lower Oyapock and in the neighboring Brazilian state of Amapá and the Kali'na settled in some villages west of the city of Kourou.

The historical Palikur nucleus was located along the Urucauá River in the Uaça Basin, in the northern part of the Brazilian state of 
Amapá (Nimuendaju 2008). At the time of the European conquest, the Palikur had a trade network that included various ethnic groups settled between the Araguari and Oyapock Rivers. During the eighteenth century, numerous communities found refuge in northern Amapá, leading to cultural mixing and assimilation. This resulted in the formation of the three Amerindian ethnic groups in this region today: the Palikur (who speak an Arawak language), Karipuna, and Uaça (Grenand and Grenand 1987). In recent times, some Kali'na also settled in the Uaça Basin. In 1982, 1,026 Palikur were reported to live in French Guiana and the Amapá State in Brazil. Ten years later, this number had risen to 1,480 (Grenand and Grenand 1994).

Today the coastal Amerindians inhabit two main areas at the two extremes of the French Guiana coast: the Kali'na area along the lower Mana River in the west and the Palikur area along the lower Oyapock River in the east. Along the rest of the western coast, only a few small Kali'na villages are found, generally settled on the sandy ridges not far from National Road 1, which runs east-west parallel to the seashore.

The Maillard village was located on a slight elevation in the old coastal plain, $6 \mathrm{~km}$ east of the modern town of Macouria and $235 \mathrm{~m}$ south of National Road 1 ( $4^{\circ} 57^{\prime} 59^{\prime \prime} \mathrm{N}, 52^{\circ} 26^{\prime} 21^{\prime \prime}$ $\mathrm{W})$. This site offered an advantageous view of the savannah, easy access to the main coastal road, and proximity to the town of Macouria (Figure 1). Inhabitants were close to various biotopes-forested patches to the south, seasonally flooded savannahs surrounding the village, and mangrove and sea to the north-allowing access to resources from these areas. They lacked only a nearby freshwater source because the closest river, the Macouria, was $7 \mathrm{~km}$ away.

A soil core from the center of the village showed two main pedologic strata. A layer of brown to yellowish-brown, clayish sand was found between 0 and $40 \mathrm{~cm}$ deep. From 40 to 60 $\mathrm{cm}$, the soil progressively became multicolored clay (bright brown, red, and grayish). The soil was very dry in comparison with the flooded surroundings. In sum, the village had been settled on a low coastal formation, with a thin sandy layer lying above a clayish substratum, which may have been formed from a sedimentary origin or from an altered rocky substratum. In inhabiting the savannah, Amerindians opted to settle in dry spots, free of flooding (Figure 2). All the archaeological test pits made between houses and in middens showed a thin superficial cultural layer, reaching a depth of less than $5 \mathrm{~cm}$.

The Maillard village was studied in two stages: first, classical archaeological fieldwork at the site was followed by an interpretation of the collected data; then, a knowledgeable former occupant of the village was interviewed. Fieldwork included topographical mapping of various features, several test pits, and an inventory of remains and midden contents.

\section{The Archaeological Approach}

Archaeological fieldwork was conducted in November 1990 at the end of the dry season, and several visits were made over the course of the subsequent year. Vegetation was still low and sparse, so remains and pathways were clearly visible. Moreover, a recent savannah fire had cleaned the central part of the village. The settlement stretched over $38 \mathrm{~m}$ from north to south and $50 \mathrm{~m}$ from west to east, but an additional house was located $22 \mathrm{~m}$ east of the eastern border.

More than 100 planimetric measurements were taken using a horizontal alidade in magnetic orientation at scale $1 / 200$. Altitude measurements confirm that the village was located on the highest point of the flood-prone savannah, so that it remained dry even during the rainy season. The first step was to locate posts and postholes in order to reconstruct the map of each individual house and of the latrines. Garbage dumps were then located and measured. A map of internal pathways was drawn. Planted trees were located and their species determined. Two wooden benches, which constituted the largest artifacts, were located. Finally, houses were numbered for the study. A complete map of the settlement was drawn showing postholes, house plans, latrines, pathways, middens, and discard areas, as well as notable artifacts, planted trees, and the central plaza (Figure 3).

\section{Settlement and Architecture}

During the topographical work, remains of seven houses were identified (Figure 4): only traces 

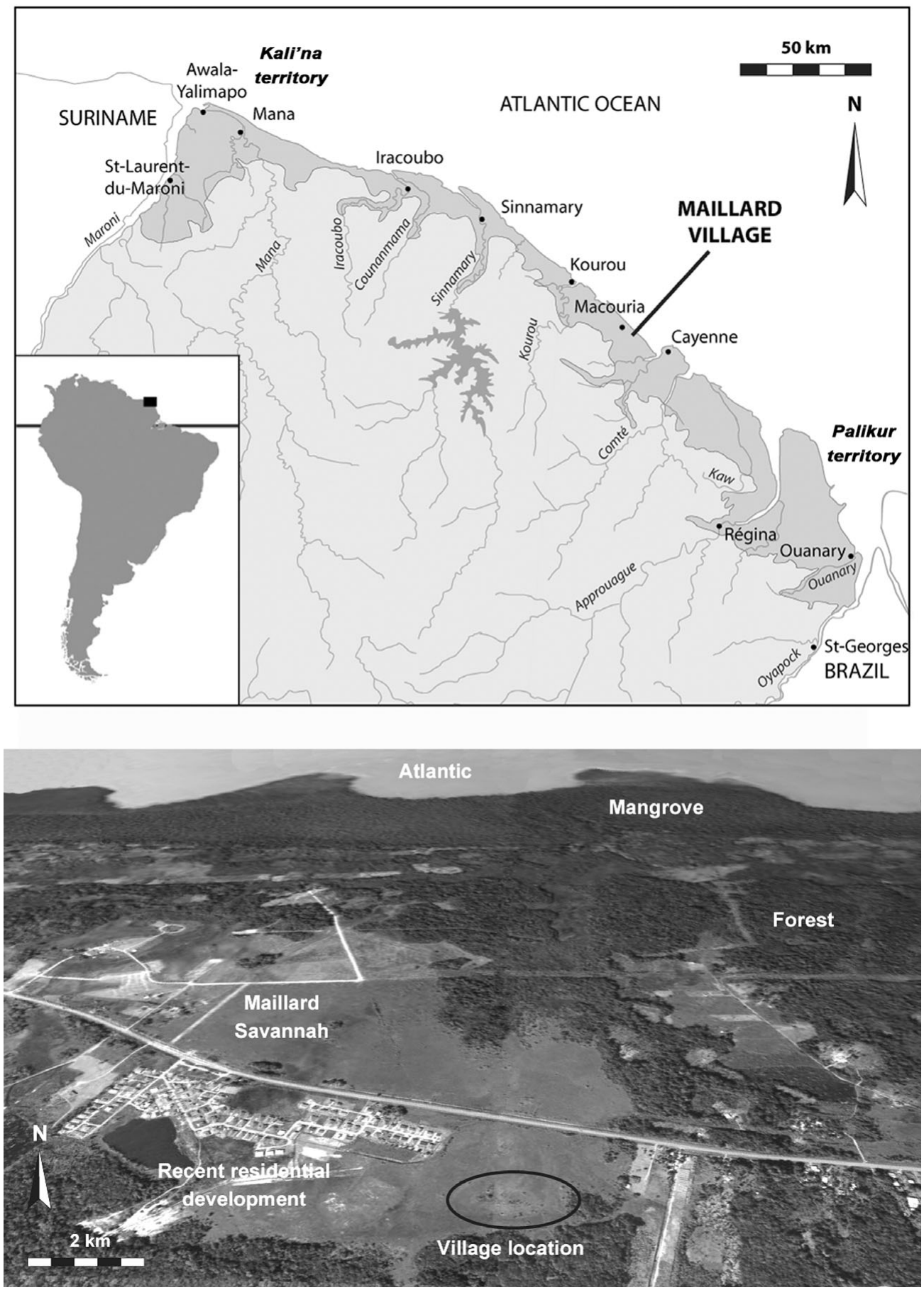

Figure 1. Location of the Maillard village on the central French Guiana coast and oblique view of the savannah from the south with the area (circle) of the Maillard village. Kamuyene village is located to the west. (Drawing S. Rostain; photo Google Earth.) 

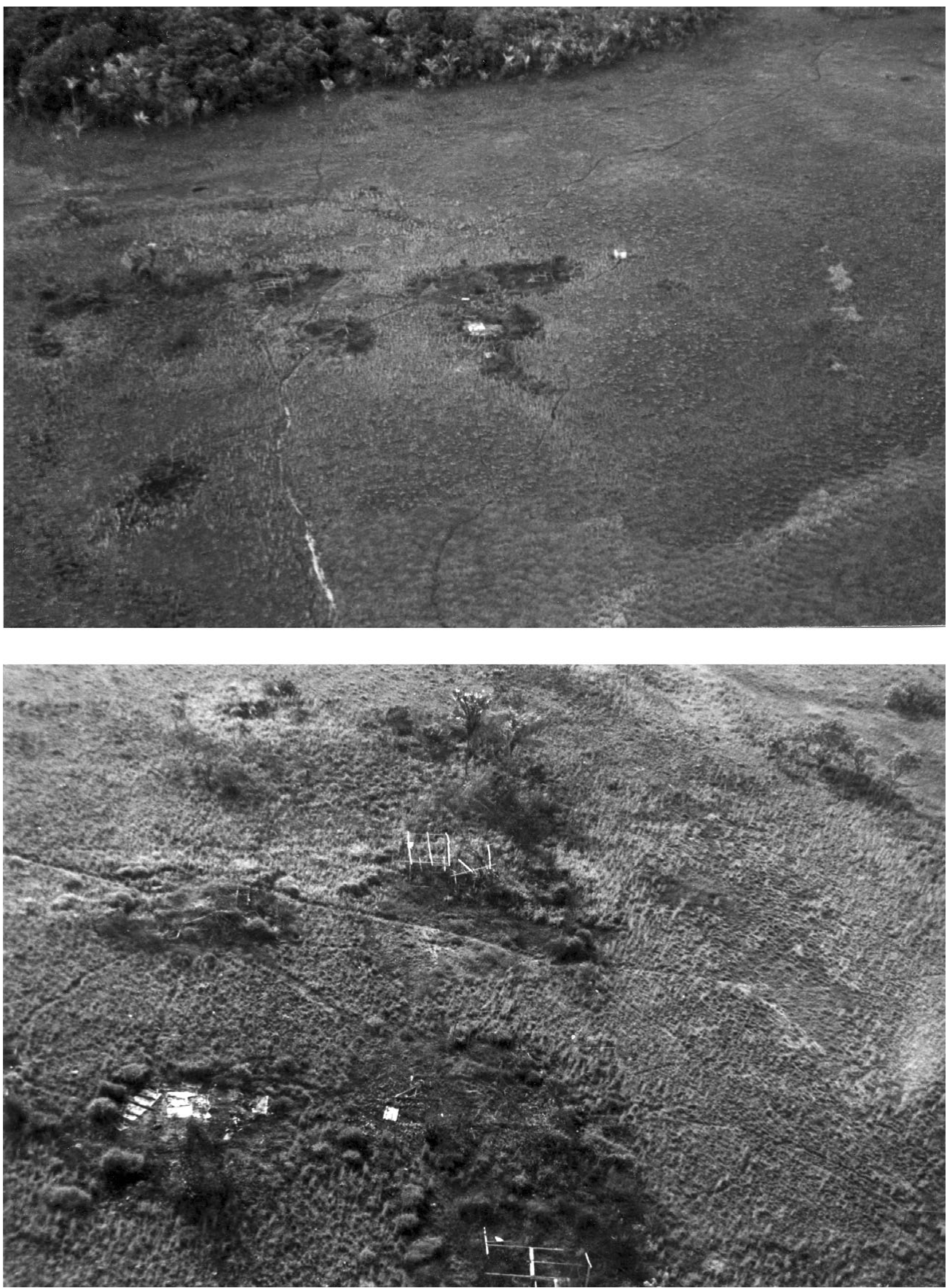

Figure 2. Aerial views of the abandoned Maillard village, from the north and from the west. Some raised fields can be seen in the foreground in the upper photograph. (Photo S. Rostain.)

remained of the first house (house 6); three were almost completely destroyed (houses 1, 2, and 7); two were partially ruined (houses 3 and 4), and one was well preserved, almost habitable (house 5). The diameter of house posts ranged from 7.5 to $9 \mathrm{~cm}$, up to $14-15 \mathrm{~cm}$ for the main 


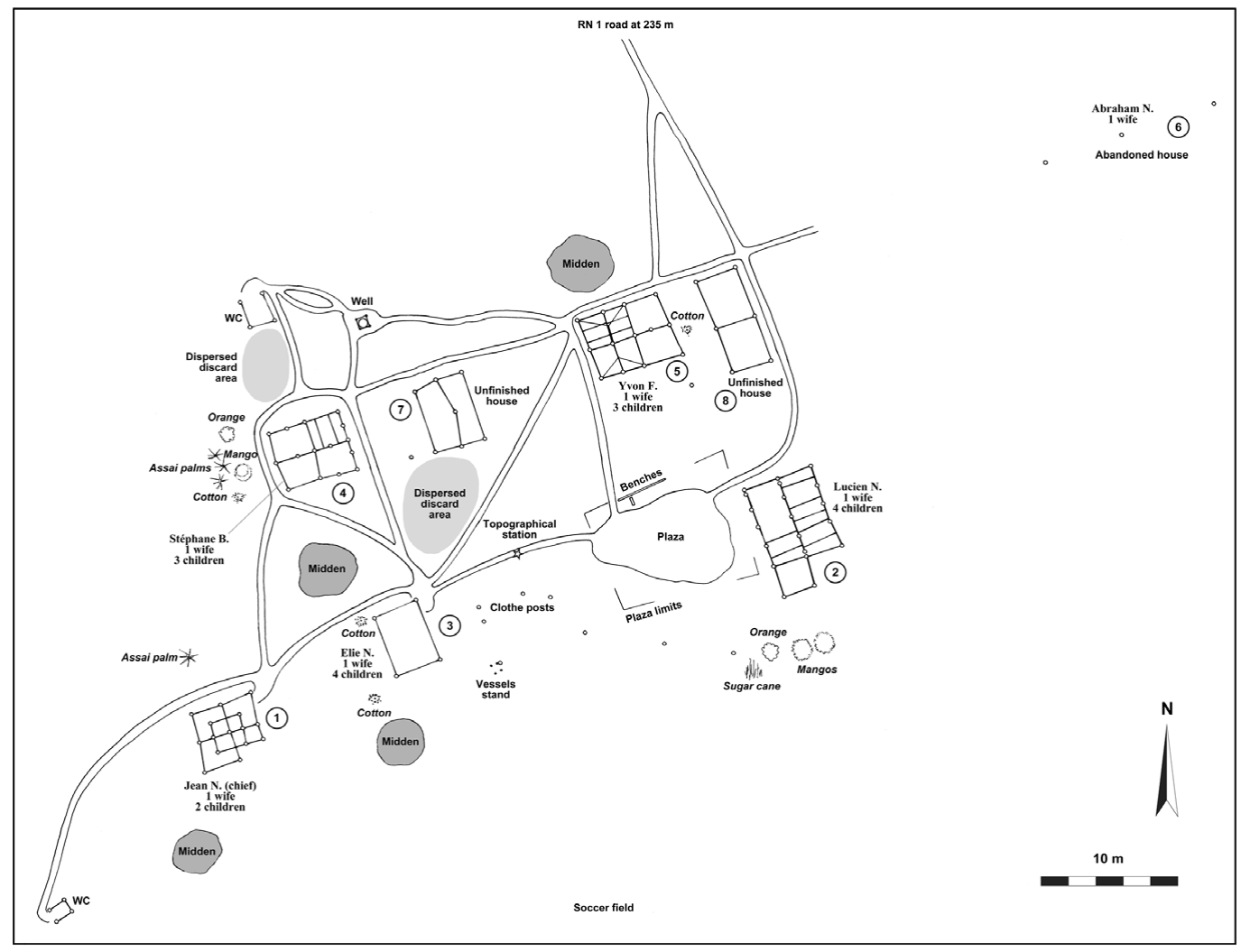

Figure 3. Interpretative map of the abandoned Maillard village. (Drawing S. Rostain.)

posts. All houses had been built on low stilts. Of houses 6 and 7, only postholes, sometimes including part of the post, were still visible. Floor beams of houses 1 and 2 were preserved. In house 3 , posts and beams supporting the floor, horizontal beams, and some palm leaves of the roof were intact. House 4 had lost its walls and floor, but still had its palm roof. House 5, the best preserved, seemed to have been abandoned more recently than the others, with its wooden posts, leaf roof, and raised floor still in good condition. The roof was made of maripa palms (Maximiliana maripa, Arecaceae) and the raised floor was made of split trunks of acai (Euterpe oleracea, Arecaceae). Several utilitarian artifacts were abandoned on the floor: an old tricycle, unfinished baskets, a pottery pitcher with lateral neck, a dented aluminum cooking pot full of coloring bark, and letters from employers. The material remnants and overall good condition of house 5 gave the impression of a hasty and recent departure, more so than the other houses.
Various features in addition to the houses were located and identified (Figure 5). Inhabitants of the settlement used only two latrines, located apart from the houses and on the northern and western periphery of the settlement. Some posts had another function than house support. Posts for clotheslines were distributed along lines at irregular intervals. Others with smaller diameter were supports for tables. Pathways and the central plaza were still clearly evident because vegetation had not regrown on their trampled and compacted soil.

Three pathways led to the well, which was located on the northern edge of the settlement. Some groups, such as the Palikur, regularly dig wells in their villages, even if they have a stream at their disposal nearby. Water wells are common not only in modern Amerindian settlements, but also in archaeological sites of the Guianas. Most were dug, probably with wooden shovels (Rostain 2010), in villages located on sandy coastal formations, especially when these were far from 

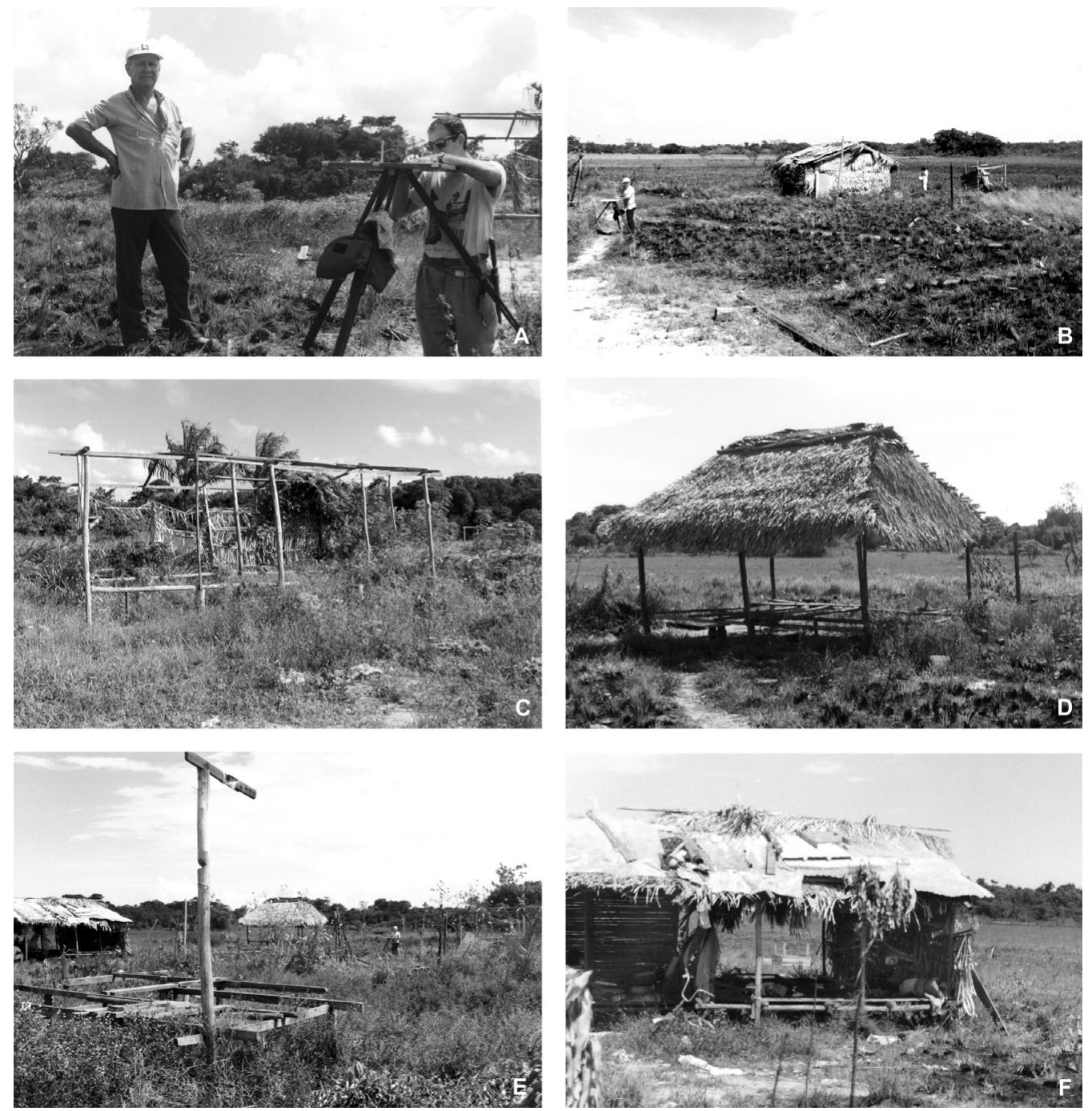

Figure 4. Topography and houses of the Maillard village: (a) topographical survey of the village; (b) house 5; (c) house 2; (d) house 4; (e) house 1 (foreground); (f) house 5. (Photos S. Rostain.)

a river. For instance, various pits interpreted as wells were found during the excavation of the precolumbian site of Katoury on Cayenne Island (Mestre and Rostain 2015).

Four garbage dumps were found near houses $1,3,4$, and 5 , as well as two dispersed discard areas near house 4 and in the center of the village. Garbage covered a surface varying between 3 and $5 \mathrm{~m}$ diameter in a layer about $20 \mathrm{~cm}$ thick. A precise inventory of each midden was made. The great majority of refuse was of European and industrial origin. Artifacts were broken and made of materials that would not resist destruction for long. Metal artifacts dominated the sample: cans, sprayers, drums, pieces of gas lamps, aluminum foil food packaging, and so on. Glass containers were numerous: bottles, flasks, pots, and baby bottles. A large quantity of spent electrical batteries was found. European earthenware and plastic bottles or containers were rarer. Several cardboard food packages were intact because the study was made during the dry season. Various usable metal containers were found in the garbage associated with house 5, including one cooking pot, one saucepan, and one pie pan. The house 5 garbage dump was the only one in 

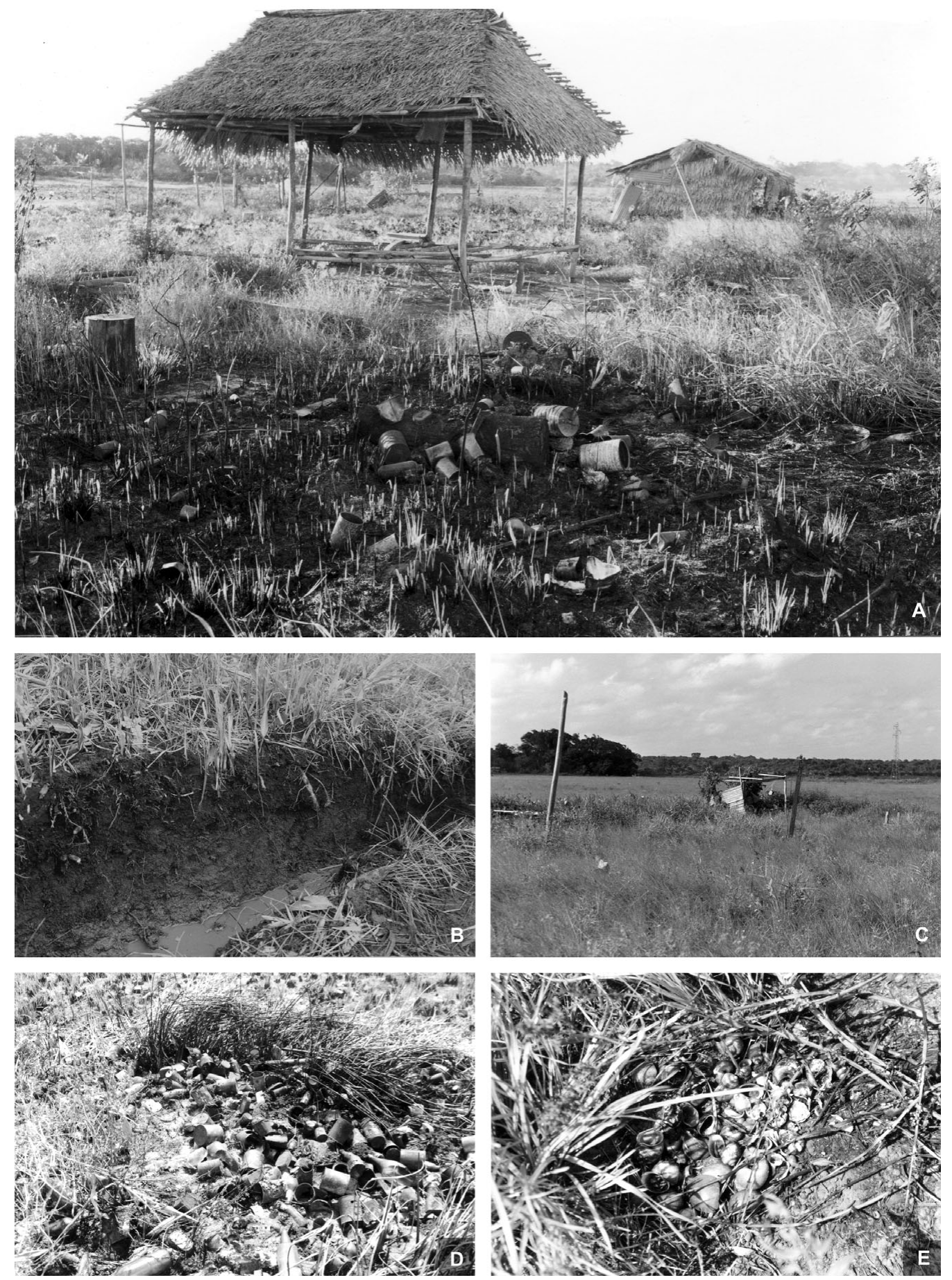

Figure 5. Various features of the Maillard village: (a) dump area behind house 5; (b) ditch for the drainage of wastewater; (c) post and latrines; (d) garbage; (e) pile of snail shells in a midden. (Photos S. Rostain.) 
the village that contained rum and wine bottles. The absence of similar remains in other middens suggests that apart from the inhabitants of house 5 , village residents did not drink alcohol. The only culinary remains were eggshells, some piles of broken nuts, and snail shells (Pomacea, Ampullaria crassa, and Neritidae).

Various useful trees and other plants grew near the houses, including acai palm, cotton (Gossypium barbadense), orange (Citrus sinensis), mango (Mangifera indica), mombin (Spondias mombin), and sugar cane (Saccharum officinarum). North of the settlement, just before the road, there was a complex of raised fields located in thalwegs. Distributed in a grid following the curve of the thalwegs, these fields were square and measured $1 \mathrm{~m}$ in diameter and $60 \mathrm{~cm}$ in height.

\section{Material Artifacts}

Few artifacts manufactured by Amerindians were found, the most notable being two wooden benches on the central plaza (Figure 6). An individual bench made out of a wooden trunk and carved roughly in the shape of a bird was found in the ceremonial plaza. This small bench had been placed against a collective bench at the edge of the central plaza. The latter bench was made from a beam $370 \mathrm{~cm}$ long and $10 \mathrm{~cm}$ wide, square in cross section (Figure 6). One end of the bench was sculpted in the shape of a stylized snake head. The beam was not perfectly straight; the snake's tail was slightly raised. The two sides were decorated with geometrical motifs and diamond shapes, painted in red, blue, and white. The general impression of the decoration evoked a snakeskin. Before being abandoned, this bench had been mutilated: the last $13 \mathrm{~cm}$ of the tail had been sawn off. The cut fragment was found near the bench.

Other small material remains were also collected in house 5 (Figure 7). One gourd bowl had a rim decorated with incisions painted in black. One lid of a metal can had been perforated with a nail to make a rasp, presumably to grate coconut (Cocos nucifera) or sweet manioc (Manihot esculenta). This was the only secondary tool we found, made out of a European object and used for a function different than its original purpose. The red bark found in a cooking pot testifies to an Amerindian activity, probably the manufacture of a dye for basketry or calabash. Only two Amerindian pottery artifacts were found (Figures 7C and 7E). One is a red painted pitcher. The pitcher is oval in section and has an inclined neck or spout to one side. The pitcher once had a wide handle, but this was broken. The second artifact is a small sherd painted with red and white motifs and with one small perforation (7 $\mathrm{mm}$ diameter).

A year after the first fieldwork, I returned to the village, but for the most part it had disappeared. House posts had been taken or had degraded naturally. Vegetation had regrown, hiding pathways and garbage. Only the center of the ceremonial plaza was still visible and not yet colonized by secondary vegetation. Various visits were made in the years that followed to track the natural degradation of the site and the disappearance of features and traces. Twenty years after the first fieldwork, in May 2009, I made another visit to the site with an ethnobotanist to evaluate the quantity of remains, useful plants, and the post-abandonment changes in the settlement. No evidence of an old settlement was visible. Even the planted trees had disappeared, destroyed by the annual savannah fires. This absence of visible remains only twenty years after abandonment indicates that coastal savannah villages may generally leave few traces of human occupation. Pawel Gorecki (1985) has pointed out, in a similar ethnoarchaeological study, that most changes in the archaeological record are effected during the first years of abandonment, after which a period of stabilization occurs.

It is easy to imagine what features might be found if excavations were conducted today: postholes, the well, latrine pits, evacuation canals, and drip lines left by rain streaming along the sides of the houses. The majority of the artifacts, mainly European, were made from perishable raw materials and would have been destroyed. It can be expected that excavation would reveal glass and earthenware containers and few Amerindian pottery vessels.

\section{Archaeological Interpretation}

The archaeological data collected was classified and analyzed using ethnographic references (for 

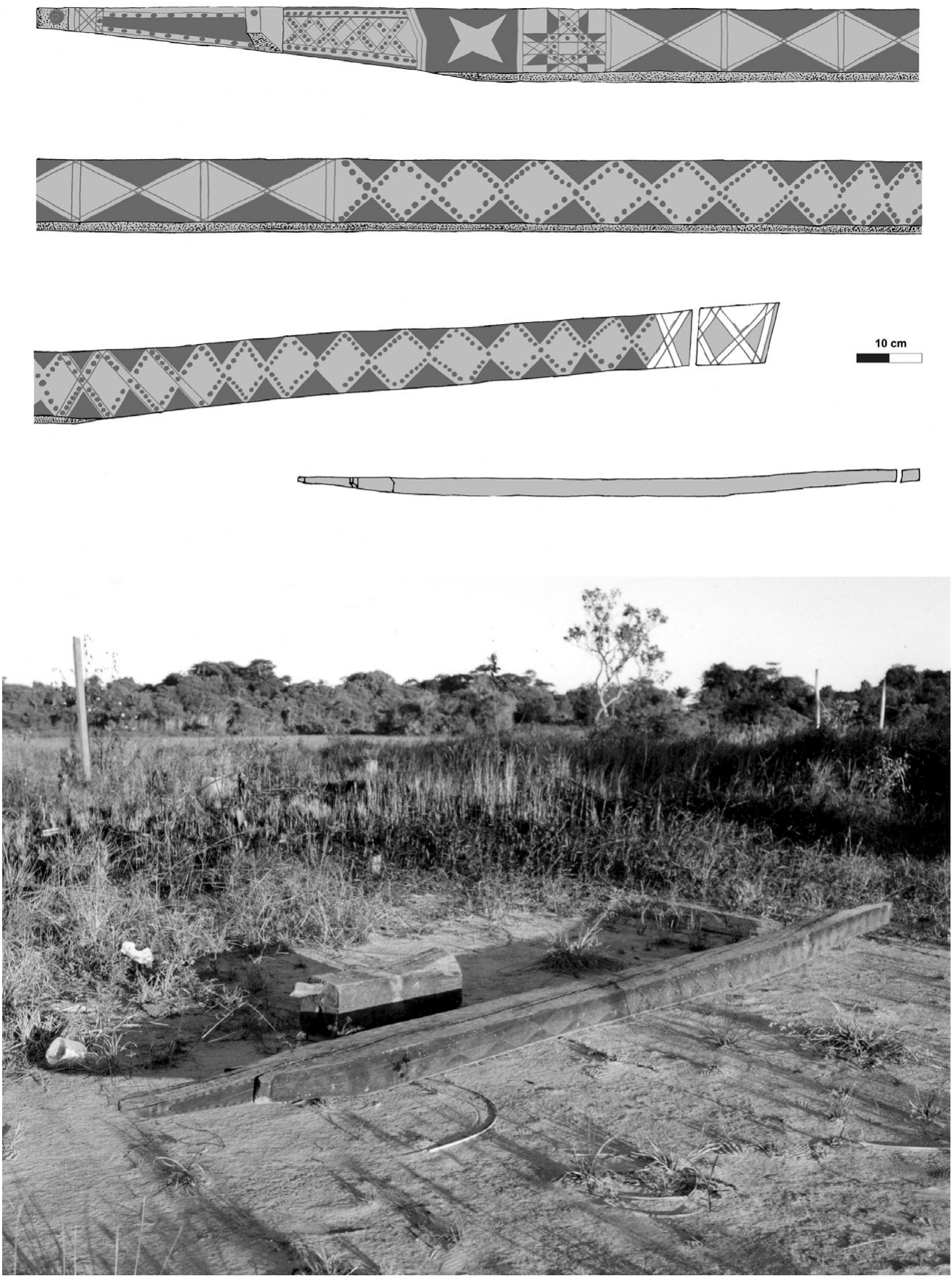

Figure 6. Wooden zoomorphic benches found in the Maillard village plaza. The drawing of the collective bench is presented in three sections. (Photos and drawing S. Rostain.)

instance, Nimuendaju 2008; Roth 1924) and known data on comparable modern populations to obtain inferences about the village and its former inhabitants.
The location of the Maillard village —on the top of a sandy ridge, not far from National Road 1 and near forest patches-was presumed to be a careful choice made by its inhabitants when they 


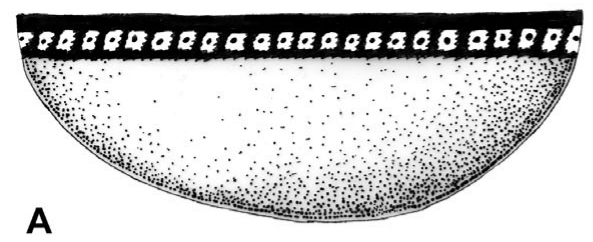

B
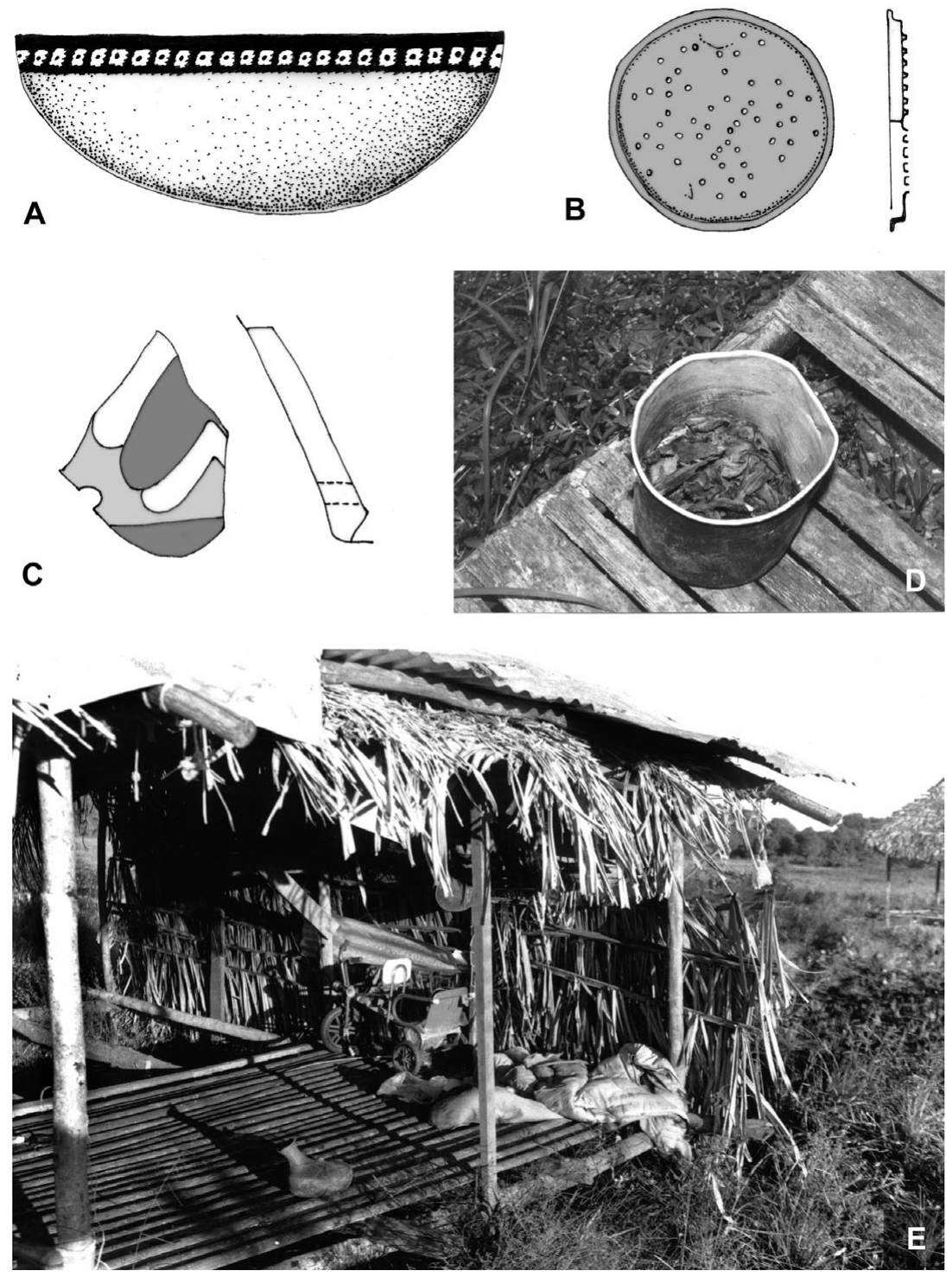

Figure 7. Artifacts in the Maillard village: (a) bowl made of an incised and painted calabash; (b) rasp made from the lid of a metal can; (c) sherd painted in red (dark gray) and white; (d) red bark presumably used for dyeing; (e) artifacts left in house 5. Among these, the Kali'na pottery pitcher watalakan can be seen in the foreground. (Photos and drawings S. Rostain.)

settled there. The spot was high and thus free of flooding, and was located near natural resources.

The mapping of posts and postholes led to the recognition of seven houses in various conditions of preservation. They were all built on stilts according to the same technique. Such houses resting on short stilts are perfectly adapted to the flood-prone savannahs of the Guianas coast.
Simple observation of the architectural style of the wood and palm houses shows that they were neither Western nor creole (the black community predominant on the French Guiana coast, who live in cement houses), but clearly Amerindian (Roth 1924). The organization of the village, with a small number of houses, external latrines, a well, pathways, and a central plaza, was typical 
of many modern Amerindian villages of the Guianas (Rivière 1984). The largest house was located just in front of the central plaza, leading to the inference that the village captain lived in this relatively prestigious building, as is the case in other Amerindian settlements. Using the characteristics of habitation features, house sizes, and indigenous birth rates in French Guiana in the 1980s, I propose that an average family consisted of three to four members. The large quantity of baby bottles in almost all garbage pits suggested the presence of children in each house. On the basis of these estimates, I hypothesized that seven families resided in the settlement, between 21 and 28 persons total.

All the characteristics seen in the village indicate a sudden departure. Benches were left in the ceremonial plaza. Numerous artifacts in working condition were still in house 5 and the red bark dye had not been taken. The fact that the collective bench tail had been sawn off could be interpreted as a ceremonial destruction and a social deposition of the bench. The abandonment was estimated to have been very recent, between several weeks and a few months before the study.

Dump areas were very informative as to daily life and the identities of the owners because most of the houses were associated with specific middens. The fact that the majority of remains were from Western industrial societies implied that a cash economy was practiced, probably supplemented by Amerindian products and local food procurement. Snail shells found in the middens indicated that local food sources could include small animals. Inhabitants could also collect wild plants from the surroundings. For their daily use, they could collect fruit from the trees between the houses. Other basic crops were probably cultivated in fields outside the village. It seems reasonable to infer that the former occupants cultivated plants on the raised fields built north of the settlement, while complementary fruits grew near the houses. I supposed that game hunting was probably practiced, although no evidence of this activity had been found.

Each midden included some common kinds of waste. For instance, most contained baby bottles, indicating the presence of infants in many families. The numerous batteries in the garbage heaps could be explained by the absence of electricity in the village, requiring inhabitants to use flashlights. The high volume of metal, glass, and plastic containers confirmed an enduring relationship with the European world and the consumption of various industrial products.

The general absence of alcohol bottles spoke in favor of a religious community ban. That is, most households were Evangelical, Adventist, or Pentecostal. Evangelical preachers' forbidding stance on alcohol could wield a strong influence on Amerindian populations. The presence of rum and wine bottles at house 5 suggested that its inhabitants did drink alcohol. This could be because the inhabitants of house 5 had not converted to Christianity or were Catholic. It must be noted that because of its location at the entrance, occupants of house 5 would have received most of the visitors to the village. When I was visiting the village in 1989, I always spoke to the male inhabitant of house 5, thinking that he was the captain. In reality, during the day he replaced the captain, who had a steady job outside the settlement. In any case, this distribution of empty alcoholic bottles could represent a religious difference like that in the Lower Oyapock, where the Evangelical Palikur of Persévérance, near Saint-Georges, did not drink alcohol but the Catholic Palikur of the Gabaret River farther north still consumed alcoholic beverages.

Another particularity that was observed was in the house 4 midden, which was full of spare car parts, suggesting that a handyman or mechanic lived there.

No Amerindian product or artifact was found in the middens, so they could not be used to identify the origin of the occupants. Even the village distribution and house characteristics were not clearly identified with a particular ethnic group. For that reason, other clues had to be used, such as the Amerindian furniture and artifacts designed in specific shapes with recognizable decorations. Morphological and stylistic features of the wooden benches were compared with examples from Amerindian peoples of the Guianas to determine a cultural attribution. The Maillard village benches appeared to be of Palikur origin. Palikur benches are generally painted with bright colors and carved in the shape of an animal that represents a spirit, called Karuãna by the Palikur (Instituto de Pesquisa e Formação en Educação 
Indígena and Museu Kuahí 2009). Individual benches may have the shape of a bird or, rarely, a caiman. The individual bench in the Maillard village was a typical Palikur bird representation, although simpler and coarser in design. There was no decorative paint, perhaps because it had eroded. This bench found on the central plaza was interpreted as having belonged to the captain because the large house 2 in front of the central plaza was assumed to have been inhabited by him.

Palikur collective benches measure from 2 to $4 \mathrm{~m}$ in length and may represent a swordfish, caiman, or anaconda. Caiman benches are destined for women while anaconda benches, often longer, are reserved for men (Instituto de Pesquisa e Formação en Educação Indígena and Museu Kuahí 2009). The bench in Maillard village was a representation of an anaconda, and thus probably intended for men. In a Palikur village, individual and collective benches are located on the central plaza and are used during ceremonies. When not in use, they are turned upside down to avoid their use by evil spirits. They are important artifacts for the community because of their essential role in the feasts at the plaza that symbolizes the cultural domain, the center of social life and most important place in the village.

A bowl made from half a calabash was found abandoned in house 4 . Its rim was decorated with a row of small squares, each with a central dot made by incision and then painted black. Palikur use the boiled bark of Licania heteromorpha (Chrysobalanaceae) to make this pigment. It was hypothesized that this motif represents the neck feathers of the stork Jabiru mycteria, as found in Palikur iconography (van den Bel 2009). In the same house, the red bark found in a cooking pot testified to the Amerindian activity of manufacturing pigments for basketry or for decorating calabashes.

The two Amerindian pottery artifacts can be attributed to the same ethnic group, the Kali'na community. The red painted pitcher with a broken handle is only made by the Kali'na. The globular shape of the pitcher is inspired by the European water jug (gargoulette in French); its porous walls are made to keep water cool. Kali'na make many of these containers, which they designate by the Karib name watalakan, created by the association of the Dutch words water and kan (jug). The perforated painted sherd was probably part of a flowerpot. In view of the technological and decorative characteristicsbeige porous paste, red and white drawings, distinctive shape (Tricornot 2007) - there is no doubt that these two ceramics were Kali'na. Such data indicate the presence of a member of this group in the village or trade relations with Kali'na.

From all the collected data, it is possible to infer the presence of one or two ethnic groups in the village. Creoles are the main contemporary inhabitants of this part of the coast, but they can be eliminated because the settlement characteristics are clearly Amerindian. Ceramic sherds and the pottery bottle are typically Kali'na, so it is reasonable to think that representatives of this group lived in this village. Nevertheless, the two wooden benches are clearly Palikur (as is the half-calabash bowl), so it can be inferred that this group also was represented here. This duality of style in the Maillard settlement might reflect the presence of residents from both the ethnic groups, but I cannot determine which one was dominant. Another possibility is that the village was occupied by one group and had trader relations with the other. Thus, not enough cultural features were found to be sure of the identity of the former inhabitants.

\section{Confronting Archaeology with Ethnographic Observations}

After completing the archaeological reconstruction in 1990, I immediately invited Jean N., who was the captain of the Maillard village before its abandonment, to the deserted settlement to test the validity of my interpretations. The objective of this exercise was to compare archaeological data against ethnographic facts. Jean was relatively open in his responses, but he remained vague on some points, especially regarding ceremonial artifacts.

The first revelation was the identity of the former inhabitants, who were all Palikur (and called themselves Paykweneh); no resident was Kali'na. According to Jean N., he was the first Palikur to settle in Maillard village in 1986. 
He was born in Saint-Georges, on the French bank of the Oyapock River, and migrated when very young with his parents to Ukumene on the Urucauá River. When he came of age, he returned to Saint-Georges, where he stayed for two years before flying to Cayenne to work and to seek good health and happiness. In 1986, he decided to build his house near Macouria. The same year, his brothers and other Palikur joined him there.

The captain's testimony enabled us to reexamine several of the archaeological interpretations. First, the location of the settlement was not a choice of the inhabitants. Rather, the municipal government of Macouria decided to place the settlement far from the town, rejecting the Palikur in the same way that numerous other Amerindian groups in the contemporary Americas were treated. Thus, the inference that a precise choice had been made by the inhabitants was invalidated.

The captain made a list of the former inhabitants including the name of the husband (but not the wife) and the number of children in each household. In 1990, 28 people-12 adults and 16 children-permanently lived in Maillard village, in an area of about $1900 \mathrm{~m}^{2}$ (this area excluded house 6 , which was set back from the settlement). Thus, the evaluation of the number of inhabitants-between 21 and 28-made during the archaeological work was correct, even if the average number of family members per household and the number of houses were wrong. The Maillard village occupants were:

House 1: Jean N. (captain) and wife, two children;

House 2: Lucien N. and wife, four children;

House 3: Elie N. and wife, four children;

House 4: Stéphane B. and wife, three children;

House 5: Yvon F. and wife, three children;

House 6: unfinished house;

House 7: unfinished house;

House 8: Abraham N. and wife.

The number of residents had fluctuated over time because sometimes Palikur workers had come from Saint-Georges to labor in the surrounding pineapple plantations. The captain explained that the village was occupied by its inhabitants for only four years because the owner of the land decided to settle a housing project in this area. Banished, most of the Palikur settlers moved away in May 1990 to settle in a new village $3 \mathrm{~km}$ closer to Macouria. Three individuals stayed in house 5 until August before moving on.

Kamuyene, the name given to the new village, is interesting because it was the name of a famous Palikur clan. The word kamu means "sun," and the name signifies that the people's eyes shone like the sun (Grenand and Grenand 1987). This clan, which originated in the Maye Hill on the Cunani River in Amapá, were outsiders who joined the Palikur and assimilated into the community by the beginning of the twentieth century (Nimuendaju 2008). I first thought that the inhabitants of Maillard village were survivors of this clan, but further ethnographic inquiry with Jean N. revealed that his family came from a group that had assimilated with the Palikur at a later time. In fact, it seems that he could even be a Marounouyene, which is not a Palikur clan but a Maroni Kali'na group. The claim of membership in the prestigious Kamuyene clan could not be verified, demonstrating the practice of embellishing oral history by members of a community. The symbolic dimension of the search for a mythical past is an important aspect in some Amerindian groups. For that reason, it is important to be cautious in ethnographic interviews when asking for genealogical precision.

In making the list of inhabitants, Jean N. omitted two houses (6 and 7), so I asked him who lived in these houses. He answered that no houses had been there. When I showed him the postholes, he explained that people had begun work on the two houses but had never finished them; at the time Maillard village was abandoned, the houses had never been inhabited. This was not obvious from the available evidence and features. An indication of this fact might have been the absence of garbage dumps associated with these houses, but a dispersed midden located just in front of house 7 resulted in the conclusion that these houses had also been occupied and abandoned. Although no discard area was associated with house 6 , it is common in Amerindian villages to sweep out the garbage against the neighbor's house, so that a dump near one house could have come from another house. Moreover, Jean N. told me that there was a house east of the settlement that I 
had not recorded. The inhabitants of house 8 had left long before the others.

In the majority of Amazonian villages, the captain's house is the largest and is usually located in front of the central plaza. It was inferred that the large house 2, just east of the ceremonial plaza, was the captain's house. "Oh no!" answered Jean N., "Mine was the small one far away [house 1], at the end of the western pathway of the settlement." The inference of social significance of the central location of the captain's house was thus invalidated. The captain said he had not wanted to live in front of the plaza because of the noise. Instead, his brother, Lucien, lived in house 2 . The captain did confirm that the owner of house 4 was a handyman, but not a professional mechanic.

The analysis of the distribution of postholes and posts to reconstruct the plan of the buildings seemed like a straightforward interpretation. Nonetheless, the multiple errors in the conclusions showcase the missteps an archaeologist may make while analyzing remnant architecture. I saw two inhabited and abandoned houses when in fact they had never been finished nor occupied, and I missed a house that had actually been used in the periphery of the village.

The two abandoned benches were clearly of Palikur origin, based on their shape and decoration. According to Jean N., the collective bench had been manufactured in Saint-Georges, in the Lower Oyapock. It was then brought to Maillard village by canoe, a difficult voyage by sea of more than $100 \mathrm{~km}$. The captain would not give a clear explanation for why the bench was abandoned, and argued that he did not know that the tail was cut or why. Perhaps the children did it, he explained. This explanation was doubtful, as I learned later that the community split to form two groups in 1990. So it can be assumed that the bench was ceremonially "killed" by amputation. The individual bench was abandoned because it was partially cracked. Nevertheless, it did not belong to the captain. My attribution of ownership of this bench was thus incorrect.

In fact, few archaeological elements of the settlement had offered concrete clues to the identity of the former occupants. Moreover, most objects, like the wooden benches, would have been destroyed by time, and the few nonperish- able artifacts, such as pottery and glass, would have led to the wrong conclusions regarding identity. The identification of an ethnic group or an archaeological culture is frequently based on the pottery, in spite of many arguments against a simple correlation (Hodder 1982; Jones 1997). The presence of Kali'na pottery in Maillard village could be explained by the absence of ceramic manufacture in the village. No women manufactured pottery in the settlement; this craft had almost completely disappeared among the Palikur by the 1980s (Rostain 1992). The closest Amerindian potters were Kali'na, and the Palikur had to trade with them to obtain Amerindian ceramics. This ethnographic evidence is very interesting for archaeologists because similar phenomena surely occurred in the past. For example, until recently in the Upper Xingu, only one group made pottery, which they traded to neighboring communities; these communities represented four different linguistic families (Steward 1948).

Work activities were divided by gender at Maillard village: all men were employed in neighboring pineapple plantations and worked in their own fields, while women manufactured and sold basketry. In addition to agriculture, men hunted various animals in the nearby forest, including agouti (Dasyprocta agouti), deer (Mazama americana), tapir (Tapirus terrestris, locally named maïpouri), toucan (Ramphastos sp., locally named gros-bec), and others. They also fished and collected shellfish (called mantouni in Palikur) in the Macouria River. The piles of snail shells were correctly interpreted as food remains.

The proximity of raised fields and settlements suggested a connection between the two activity areas. Nevertheless, Jean explained that the village residents had never cultivated these raised fields, nor had they even known their function. In reality, the raised fields were built and used around 800 years ago by Arauquinoid people (Rostain 2010). Similar raised fields are known along the Guianas coast, in an area $600 \mathrm{~km}$ long, from Cayenne Island in French Guiana west to the Berbice River in Guyana (Rostain 2008). They are mostly precolumbian, built between A.D. 300 and 1400 by Barrancoid or Arauquinoid societies. They were used to 
cultivate crops, mainly maize, in flood-prone areas such as the coastal savannahs and swamps. This agricultural technique almost disappeared after the European conquest, but recently small groups, including Haitian migrants and Saamaka (descendants of escaped African slaves), have built and cultivated similar raised fields along the western French Guiana coast (Rostain 2012). The inhabitants of the Maillard village had, conversely, cultivated three fields using slashand-burn technique in the forested patches south of the settlement. The chance spatial association of ancient raised fields and the remains of a modern settlement led to a false conclusion about activity areas (see Supplemental Information 4).

During the study of the Maillard village, some aspects were difficult to register and I missed some remains. The abandoned and ruined house 8 was covered by grass and some postholes were not visible, so only three postholes had been located during the topographical survey of the site. I did not find the posthole of the ceremonial pole that had been removed from the central plaza. This was a pity, because this pole is very important for the feasts and dances that were organized twice a week in Palikur villages (Instituto de Pesquisa e Formação en Educação Indígena and Museu Kuahí 2009). The central pole generally measures between 4 and $6 \mathrm{~m}$, but can reach $7 \mathrm{~m}$ high. It is decorated with grooved motifs, painted figures, and feathers that were spirit emblems. One to four poles, simple or equipped with arms, may be planted on the ceremonial plaza. During the Turé feast, strings tied to the beams of the pole symbolize a house roof. The central plaza is an essential space for the community, because the pole connects spirits and humans through the efforts of the shaman. The ceremonial pole is the passage taken by the spirits to participate in the feast, when all the village members are present around the pole. The Turé is the most important feast for the Palikur, because it serves to thank invisible spirits living in the Other World for the cure during shamanistic practices (Vidal 2009). Jean N. told me that the ceremonial pole was not the only element missing from the central plaza. Former inhabitants had taken another large collective bench and four individual benches, those of
Lucien, Jean, and Elie N., and one reserved for guests.

Finally, I did not see the remains of the soccer field, which was under the grass at the southern edge of the village. I did not look for the goal postholes because they were outside the settlement and hidden in the vegetation.

In fact, I failed to detect two essential parts of Palikur community life: sports and ceremonies. I did not pay attention to the discreet-but present-traces of these domains of village life because I was not aware of the practice of these activities.

Over the course of the year following the initial study of the Maillard village, I returned to make regular observations to see what artifacts were taken by Amerindians when they came back to their ancient village (Figure 8). The abandonment of various usable artifacts, such as sheet metal, toys, basketry, and pottery, had suggested that they had moved rather abruptly. Consequently, the ease of access to the settlement and its proximity to the new village allowed them to return frequently to retrieve objects that could be put to use again. The Amerindian people of the Guianas have been noted to possess an indifference to objects and a lack of attachment to material assets (Rivière 1984). For instance, during my visit with the captain, he took advantage of my car to carry sheets of metal to the new settlement. He noted the well-preserved posts, planning to return to take them later, and one of his children took the tricycle that had been left in house 5 (Figure 7E). Thus, former inhabitants tended to visit their abandoned settlement for the purpose of reclaiming some of the resources that the area contains.

\section{Conclusion}

The objective of the Maillard village project was to test the viability of interpretation used by archaeologists in the tropics. In the 1980s, no specific methodology had been developed in the rainforest, so inferences were made without a strict process. In the Maillard village, the archaeological approach that was undertaken was the same as that used at precolumbian sites, such as digging of test pits, recording of the spatial distribution of features and artifacts, elaboration of a 

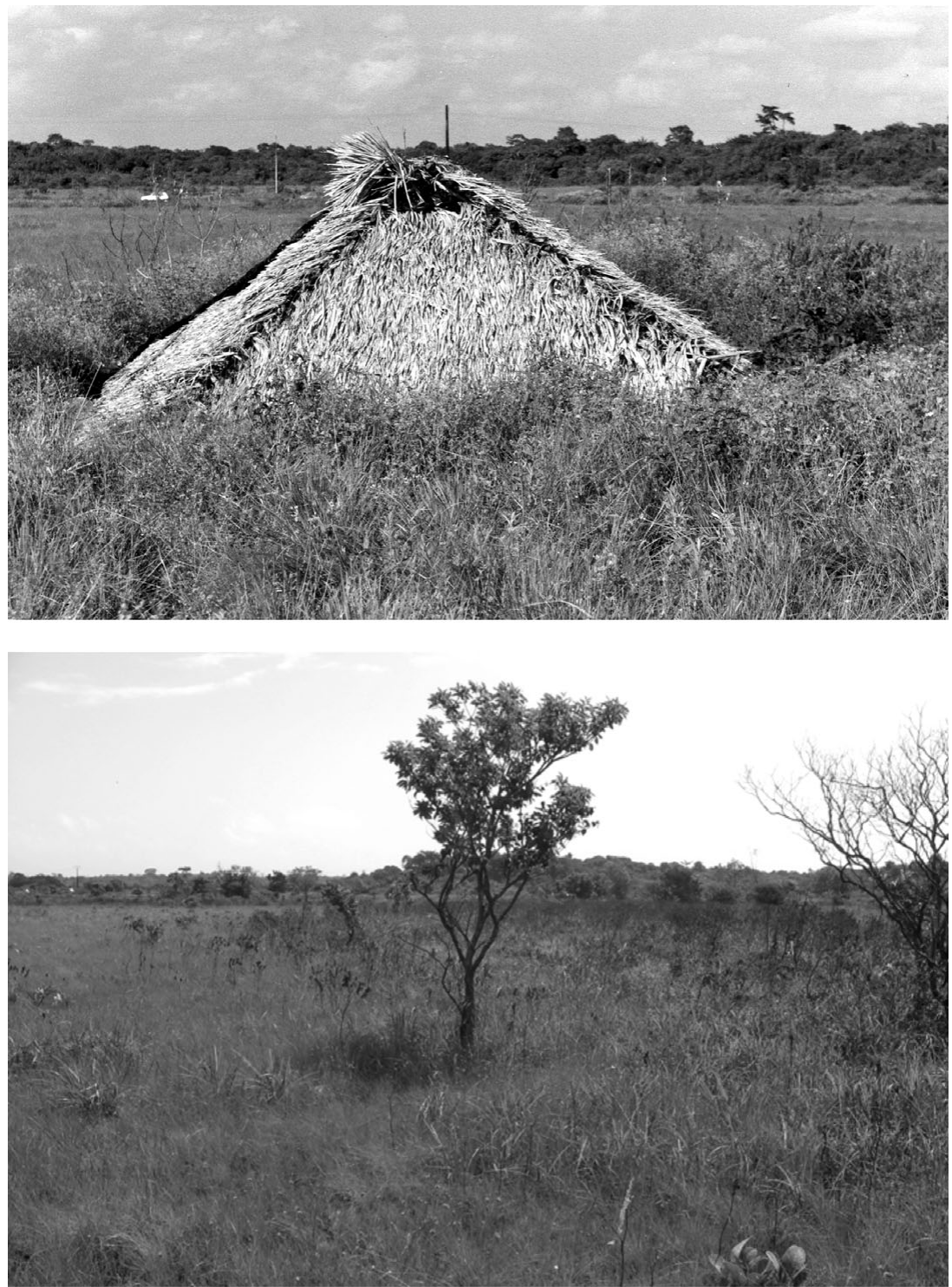

Figure 8. The top photograph shows Maillard village one year after abandonment, with houses that had almost completely disintegrated, as illustrated here by a fallen roof. The lower photograph shows that 20 years later the village exhibited no visible human-related features and no relictual planted trees. (Photos S. Rostain.)

precise topographical map, and interpretation of data. Following the archaeological investigation, former residents of the village were questioned on the aspects revealed by the archaeological inquiry to check the accuracy of the proposed inferences. This experiment revealed the fallibility of the inferential process, showing that the archaeological data were easy to misunderstand in many cases.
What can we conclude from such a Popperian experiment? The experimental study of the Maillard village allows us to evaluate the relevance of the intuitive analytical approach. The inferential process used for archaeological interpretation led to crucial errors in the conclusions when confronted with the information from the ethnographic interview. Four main mistakes can be recognized: 
1) Social organization and occupation of the settlement were misidentified (selection of the settlement location, identification of unfinished houses, attribution of a house to the captain).

2) A wrong ethnic identification was made (Palikur/Kali'na).

3) An activity area was erroneously identified (raised fields, not contemporaneous with the occupation of the site).

4) Important features were missed (a house out of village bounds, the posthole of the ceremonial pole, the soccer field).

Unfortunately, these are not insignificant errors, but essential misunderstandings that invalidated a large part of the proposed conclusions drawn from the archaeological work. Most of these errors resulted from the inferential process applied to the chain of successive interpretations. The logical conclusions provided by the archaeological study had to be significantly reassessed in light of the ethnographical revelations. The vulnerability of the intuitive analytic approach suggests that it should be critically examined before it is used for the interpretation of archaeological data.

Conversely, ethnographic data were not devoid of mistakes either, because the situation was described through the distorted filter of the subjectivity of the witness, not to mention the limits to the accuracy of his memory. In the Maillard village, the captain gave evasive or inexact answers on the reasons for the abandonment of the settlement and the "deconsecration" of the collective Amazonian bench. The interviewer must keep in mind that interlocutors are influenced by cultural rules and interdictions. This problem has been extensively explored by the Tucson Garbage Project conducted by William Rathje (Rathje and Murphy 1992; Rathje and Ritenbaugh 1984).

This ethnoarchaeological experiment also provided successful guesses and positive conclusions. Reconstructions of house plans on the basis of the posthole distribution were correct, even if two of these buildings were never finished. In these cases, close observation of the data could have helped avoid misinterpretations, such as a more careful recording of the presence or absence of associated middens. The small size of the settlement and the organization of domestic space were correctly interpreted as belonging to a small-scale, egalitarian society of low-level food producers. The plaza was correctly interpreted as an important social and ritual space based on its central location and the presence of two ceremonial benches. Perhaps one of the most interesting conclusions was that not all houses in a settlement are occupied simultaneously and permanently, something that archaeologists tend to forget.

The reasons for location and abandonment of the village were misunderstood because of the intrusion of modern circumstances and European presence. The municipal government marginalized the Palikur community by settling them in the old coastal plain. A few years later, they were again pushed away by the landowner and had to move to a new village. Such conditions have no correlation in the prehistoric past.

Inferences about demographics were correct. Despite difficulties in evaluating the mobility of the inhabitants, house abandonment or reoccupation, remoteness of structures, and so on, the evaluation of number of residents was accurate. The observation that the inhabitants' departure had been sudden was correct. The study of remains and houses made it possible to define the chronology of abandonments and the analysis of the middens helped create an accurate characterization of the former users.

Nevertheless, the methodological approach of such excavations in contemporaneous settlements cannot be completely applied to the archaeological study of a precolumbian site. The high percentage of industrialized artifacts and European remains prevented a definite identification of the local culture. What was found was obviously not representative of a typical Amerindian assemblage. In Maillard village, metallic and plastic items replaced many lithic, bone, and wooden artifacts. In an Amerindian settlement without contact with the European world, the sample would have been fairly different. Because of this strong external interference, crucial identifiers of Amerindian material culture were missing. The two pottery sherds were insufficient to define the ethnic affiliation of the former inhabitants. But even a larger 
ceramic sample would not have provided a better basis for interpretation. Even setting aside the industrialized items, the comprehensive study of all Amerindian remains at the Maillard village showed a juxtaposition of two cultures, and this made it difficult to define the inhabitants' identity. It is well known that pottery is an important trade product in Amazonia and the Guianas. Kali'na frequently exchange their products with other tribes. Ethnic communities consuming the pottery of other groups is far from unusual (Gallay et al. 1996). This work demonstrated that the combination of archaeology and ethnology gives a better image of past reality. It suggests that we should be prudent in interpretations and hypotheses, especially in the tropical lowlands, where archaeological preservation is particularly poor.

In sum, the Maillard village experiment shows the risk of distortion and misinterpretation during the process of making inferences based on archaeological data. Cultural differences can lead to important mistakes in the archaeologist-ethnographer's understanding of the people he interviews. Ethnoarchaeological experiments like the Maillard village study can help us to better understand formation processes of archaeological deposits and distribution of features. This can help reduce the risk of misinterpretation of archaeological evidence in tropical environments. Such a study serves as an example of the complexity involved in interpreting archaeological data from the excavation of precolumbian sites and the prudence that the researcher must show in drawing his or her conclusions. Here, as elsewhere, the archaeological question "Who's there?" is never easy to answer.

\begin{abstract}
Acknowledgments. I thank Captain Jean N. for his participation, the topographer Pierre Frenay for his help during the mapping, the pedologist Bernard Barthés for the soil analysis, and the ethnobotanist Marie Fleury for coming with me to the site in 2009. I thank the reviewers for their useful comments. I finally thank my colleagues and friends, José Oliver and Doyle McKey, for their suggestions and for correcting my so "Frenchy" English.
\end{abstract}

Data Availability Statement. All the available data of the project are presented in this paper.

Supplemental Materials. Supplemental materials are linked to the online version of this article, which is accessible via the SAA member login at https://doi.org/10.1017/laq.2016.5
Supplemental Information 1. "Ethnoarchaeology" presents a few important references on ethnoarchaeology.

Supplemental Information 2. "Ethnoarchaeological Studies in Amazonia" lists some ethnoarchaeological studies in Amazonia not referenced in the text.

Supplemental Information 3. "Doctoral Dissertations" cites the main Ph.D. thesis in Amazonian ethnoarchaeology.

Supplemental Information 4. "Comparative Note" provides one example of another wrong chronological attribution of archaeological structures in French Guiana.

\section{References Cited}

Bonnichsen, Robson

1973 Millie's Camp: An Experiment in Archaeology. World Archaeology 4(3):277-291.

Bowser, Brenda J.

2004 The Amazonian House: A Place of Women's Politics, Pottery, and Prestige. Expedition 46(2):18-23.

Bowser, Brenda J., and John Q. Patton

2004 Domestic Spaces as Public Places: An Ethnoarchaeological Case Study of Houses, Gender, and Politics in the Ecuadorian Amazon. Journal of Archaeological Method and Theory 11(2):157-181.

Cameron, Catherine M., and Steve A. Tomka (editors)

1993 The Abandonment of Settlements and Regions: Ethnoarchaeological and Archaeological Approaches. Cambridge University Press, Cambridge.

Collomb, Gérard

2015 Les peuples qui habitent ces rivières. In Archéologie de l'Amazonie: Les premiers habitants de la Guyane côtière, edited by Stéphen Rostain, pp. 167-173. Paris Monographs in American Archaeology 44, BAR International Series 2758. British Archaeological Reports, Oxford.

DeBoer, Warren R., and Donald W. Lathrap

1979 The Making and Breaking of Shipibo-Conibo Ceramics. In Ethnoarchaeology: Implications of Ethnography for Archaeology, edited by Carol Kramer, pp. 102-138. Columbia University Press, New York.

de Pierrebourg, Fabienne

1999 L'espace domestique maya: Une approche ethnoarchéologique au Yucatan (Mexique), Paris Monographs in American Archaeology 3, BAR International Series 764. British Archaeological Reports, Oxford.

Duin, Renzo

2014 Ethnographic and Archaeological "Cultures" in Guiana, Northern Amazonia. In Antes de Orellana: Actas del 3er Encuentro Internacional de Arqueología Amazónica, edited by Stéphen Rostain, pp. 89-95. IFEA/FLACSO/EEUU Embassy, Quito.

Gallay, Alain, Eric Huysecom, Anne Mayor, and Grégoire de Ceuninck

1996 Hier et Aujourd'hui: des Poteries et des Femmes, Céramiques Traditionnelles du Mali. Département d'Anthropologie et d'Écologie, Université de Genève, Switzerland.

Gorecki, Pawel

1985 Ethnoarchaeology: The Need for a Post-mortem Enquiry. World Archaeology 17(2):175-191.

Grenand, Pierre, and Françoise Grenand

1987 La Côte d'Amapá, de la Bouche de l'Amazonie à la Baie d'Oyapock, à Travers la Tradition Orale Palikur. Boletim do Museu Paraense Emilio Goeldi 3(1):1-77. 
1994 Grande Amazonie. In Situation des Populations Indigènes des Forêts Denses Humides, edited by Serge Bahuchet, pp. 89-175. DG XII Environnement, Office des Publications Officielles des Communautés Européennes, Brussels/Luxembourg.

Hodder, Ian

1982 Symbols in Action: Ethnoarchaeological Studies of Material Culture. Cambridge University Press, Cambridge.

Hurault, Jean-Marcel

1989 Français et Indiens en Guyane (1604-1972). Guyane Presse Diffusion, Cayenne.

Instituto de Pesquisa e Formação en Educação Indígena and Museu Kuahí

2009 Turé dos Povos Indígenas do Oiapoque. IEPÉ/Museu do Indio/Funai, Rio de Janeiro.

Jones, Siân

1997 The Archaeology of Ethnicity: Constructing Identities in the Past and Present. Psychology Press, New York.

Laming-Emperaire, Annette, Maria José Menezes, and Margarida Davina Andreata

1978 O Trabalho da Pedra entre os Xetá da Serra dos Dourados, Estado do Paraná. Coleção Museu Paulista 2, série ensaios, 19-82. Museu Paulista, São Paulo.

Lange, Frederick W., and Charles R. Rydberg

1972 Abandonment and Post-abandonment Behavior at the Rural Central American House-site. American Antiquity 37:419-432.

Lucas, Gavin

2012 Understanding the Archaeological Record. Cambridge University Press, Cambridge.

Mans, Jimmy L. J. A.

2014 Betwixt and Between: Unraveling Material Histories in the Southern Guyana-Suriname Borderland. In Antes de Orellana: Actas del 3er Encuentro Internacional de Arqueología Amazónica, edited by Stéphen Rostain, pp. 359-366. IFEA/FLACSO/EEUU Embassy, Quito.

Mestre, Mickaël, and Stéphen Rostain

2015 Villages Précolombiens de Plage. In Archéologie de l'Amazonie: Les premiers habitants de la Guyane côtière, edited by Stéphen Rostain, pp. 75-89. Paris Monographs in American Archaeology 44, BAR International Series 2758. British Archaeological Reports, Oxford.

Nimuendaju, Curt

2008 [1926] Les Indiens Palikur et Leurs Voisins. Encyclopédie Palikur 1. Éditions du Comité des travaux historiques et scientifiques, Presses Universitaires d'Orléans, Orleans.

Politis, Gustavo

2007 Nukak: Ethnoarchaeology of an Amazonian People. Left Coast Press, Walnut Creek, California.

Rathje, William L., and Cullen Murphy

1992 Rubbish! The Archaeology of Garbage. HarperCollins, New York.

Rathje, William L., and Cheryl K. Ritenbaugh (editors)

1984 Household Refuse Analysis Theory: Method and Applications in Social Science. Sage Publications, Beverly Hills, California.

Rivière, Peter

1984 Individual and Society in Guiana: A comparative study of Amerindian Social Organization. Cambridge Studies in Social Anthropology. Cambridge University Press, Cambridge.
Roe, Peter, and Peter Siegel

1982 The Life History of a Shipibo Compound: Ethnoarchaeology in the Peruvian Montaña. Journal of Archaeology and Anthropology 5(2): 94-118.

Rostain, Stéphen

1992 La Céramique Amérindienne de Guyane Française. Bulletin de la Société Suisse des Américanistes 55/56:93-127.

2006 Etnoarqueología de la casa Huapula y Jívaro. Bulletin de l'Institut Français d'Études Andines 35(3):337-346

2008 Agricultural Earthworks on the French Guiana Coast. In Handbook of South American Archaeology, edited by Helaine Silverman and William Isbell, pp. 217-234. Springer/Kluwer/Plenum, New York.

2010 Precolumbian Earthworks in Coastal Amazonia. Diversity 2(3):331-352.

2011 Ethnoarchaeologogy of the Amazonian House: Pre-Columbian and Jivaro Continuity in Ecuador. In Communities in Contact: Essays in Archaeology, Ethnohistory \& Ethnography of the Amerindian Circum-Caribbean, edited by Corinne L. Hofman and Anne van Duijvenbode, pp. 455-475. Sidestone Press, Leiden.

2012 Islands in the Rainforest: Landscape Management in Pre-Columbian Amazonia. Left Coast Press, Walnut Creek, California.

Roth, Walter

1924 An Introductory Study of the Arts, Crafts and Customs of the Guiana Indian. 38th Annual Report of the U.S. Bureau of American Ethnology (1916-1917). Smithsonian Institution, Washington, D.C.

Schiffer, Michael B.

1987 Formation Processes of the Archaeological Record. University of New Mexico Press, Albuquerque.

Siegel, Peter E.

1990 Demographic and Architectural Retrodiction: An Ethnoarchaeological Case Study in the South American Tropical Lowlands. Latin American Antiquity 1:319 346.

1991 Ethnoarchaeological Study in a Waiwai Village in the Tropical Forest of Southern Guyana. In Proceedings of the XIth International Congress of Caribbean Archaeology, pp. 400-417. Fundación Arqueológica, Antropológica e Histórica de Puerto Rico/Universidad de Puerto Rico/U.S. Forest Service.

Siegel, Peter E., and Peter G. Roe

1986 Shipibo Archaeo-ethnography: Site Formation Processes and Archaeological Interpretation. World Archaeology 18(1):96-115.

Steward, Julian H. (editor)

1948 Handbook of South American Indians, Volume 3: The Tropical Forest Tribes. Bureau of American Ethnology, Bulletin 143. Smithsonian Institution, Washington, D.C.

Tricornot, Marie-Chantal de

2007 L'art céramique des Kalina. Vents d'ailleurs, La Roque d'Anthéron, Paris.

van den Bel, Martijn

2009 The Palikur Potters: An Ethnoarchaeological Case Study on the Palikur Pottery Tradition of French Guiana and Amapá, Brazil. Boletim do Museu Paraense Emílio Goeldi, Ciêncas Humanas 4(1):9-56. 
Vidal, Lux B.

2009 Povos Indígenas do Baixo Oiapoque: O eencontro das Águas, o Encruzo dos Saberes e a Arte de Viver. Museo do Índio/Iepé, Rio de Janeiro.

Zeidler, James A.

1983 La etnoarqueología de una vivienda Achuar y sus implicaciones arqueológicas. Miscelánea Antropológica Ecuatoriana 3, pp. 156-194. Boletín de los Museos del Banco Central del Ecuador, Quito.

\section{Note}

1. Only the initial is indicated to preserve the anonymity of the former inhabitants.

Submitted August 11, 2015; Revised April 12, 2016; Accepted November 22, 2016 